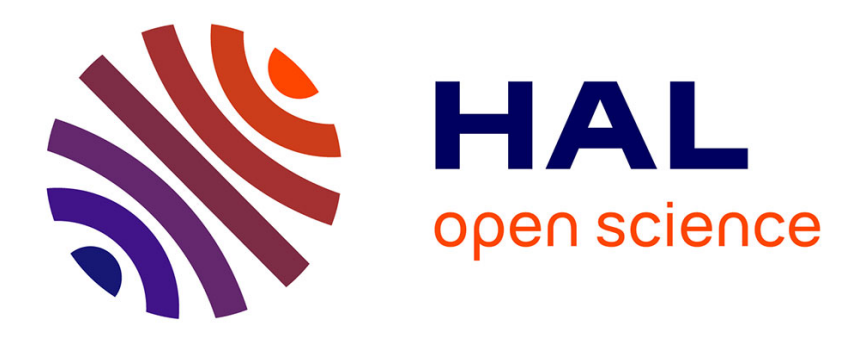

\title{
Explaining the spatio-seasonal variation of fires by their causes: the case of southeastern France
}

\author{
A. Ganteaume, F. Guerra
}

\section{To cite this version:}

A. Ganteaume, F. Guerra. Explaining the spatio-seasonal variation of fires by their causes: the case of southeastern France. Applied Geography, 2018, 90, pp.69-81. 10.1016/j.apgeog.2017.11.012 . hal-02608461

\section{HAL Id: hal-02608461 https://hal.inrae.fr/hal-02608461}

Submitted on 16 May 2020

HAL is a multi-disciplinary open access archive for the deposit and dissemination of scientific research documents, whether they are published or not. The documents may come from teaching and research institutions in France or abroad, or from public or private research centers.
L'archive ouverte pluridisciplinaire HAL, est destinée au dépôt et à la diffusion de documents scientifiques de niveau recherche, publiés ou non, émanant des établissements d'enseignement et de recherche français ou étrangers, des laboratoires publics ou privés. 
1 Explaining the spatio-seasonal variation of fires by their causes: the case of southeastern

2 France

3 Ganteaume Anne* and Fabien Guerra

4 IRSTEA, RECOVER-EMR, CS 40061, 13182 Aix-en-Provence, France

$5 \quad *$ : Corresponding author

6

7 Highlights:

- The spatial and seasonal variation of fire metrics could be due to the spatial and seasonal variation of fire causes.

- Undetermined arson and negligence during agricultural work which had a strong

- Some causes showed a strong seasonal pattern due to the seasonality of the practices.

- In the whole study area, knowledge of fire causes was poor and the high contribution of unknown causes to the total burned area underlined the necessity to improve this knowledge.

\section{Introduction}

In France, the South-East is the region the most affected by wildfires (on average $65 \%$ of the

19 total occurrence in France during the past decades according to EC 2016, and up to $80 \%$ in

202003 according to EC 2004). Large fires (size $\geq 100$ ha) which were mostly deliberate summer

21 fires represented less than $1 \%$ of the total occurrence, but were responsible for more than $70 \%$

22 of the total burned area (Ganteaume and Jappiot 2013). However, according to these authors,

23 the entire area was not affected in the same way, as its southeasternmost part concentrated the 
highest occurrence and the largest area burned by large fires. In SE France, according to the climate change, a shift in fire occurrence and fire size may occur, especially in the northern part of the region which currently presents less severe climate conditions; thus, is less impacted by fires.

During the last decades, in most Mediterranean regions, the increase in wildland-urban interfaces (WUI) has led to an increase in the number of ignitions, which were mostly humancaused (Keeley and Fotheringham 2001; Prestemon et al. 2002; Badia-Perpinyá and PallaresBarbera 2006; Romero-Calcerrada et al. 2008; Syphard et al. 2008). This trend has also been identified in SE France (Lampin-Maillet et al. 2010) and WUIs have been highlighted to be a significant explanatory factor of fire density at the local scale in this area (Ganteaume and Long-Fournel 2015). This part of France is also highly populated and characterized by a high tourist pressure, especially in summer, making this region a highly sensitive area.

With the increasing fire issue, fire policy and management mainly focus on fire suppression, but also on fire prevention. Accordingly, since the past decades, investigations on fire causes have been more and more developed (with varying levels of efficiency according to the region or country) to further improve prevention. Most previous works focused on the identification of the main driving factors of fire occurrence, density, or spread in the Mediterranean basin (i.e. Catry et al. 2009; Koutsias et al. 2012; Diaz-Delgado et al. 2004; Penman et al. 2013, 2014; Ganteaume and Jappiot 2013; Ganteaume and Long-Fournel 2015). Some works linked causes and spatial and/or temporal analysis of ignitions (Genton et al. 2006), or hotspot of ignitions (Bar-Massada et al. 2012; Gonzalez-Olabarria et al. 2012) according to their environment (Stephens 2005; Penman et al. 2013, Syphard and Keeley 2015). However, most works did not differentiate the fire causes responsible for larger burned area and for higher occurrence (which may not be the same), nor investigate in depth the spatial and seasonal variation of these fire metrics according to the causes, as did the current 
work. Besides, the novelty in this work was to present the effects of interactions between regions, seasons and fire causes on the number of fires and their burned area. Moreover, working on the detailed nature of fire causes (and not just on the main classes, i.e. natural, negligence, and arson), especially those related to deliberate fires, was an added-value to this contribution.

Given the gaps previously identified, our main objectives were to determine and to better understand (i) how the fire metrics varied within SE France, in identifying different regions that showed the same trends of environmental and socio-economic characteristics, (ii) a possible spatial and seasonal variation of the main fire causes that could correspond to the variation of the fire metrics, and (iii) which causes were more deleterious (in terms of burned area) but, also, in some cases, which ones could be easily mitigated. Achieving these goals will help to more accurately target fire prevention in the SE part of France.

\section{Material and methods}

\subsection{Study area}

The study area was located in the southeastern part of France which is composed of 15 administrative districts, called "départements", that represent a total surface area of 7,951,500 ha (Fig 1). Some of them are frequently subjected to wildfires. The cover of the different flammable fuel types varies within the study area (15 to $70 \%$ of forests and shrublands, for instance), mainly according to the nature of the bedrock (acidic soils located in the most easterly part as well as in the mountains, and limestone-derived soils located more to the West) and to the altitude. Mostly, in the study area, the fire regime, especially the fire recurrence, helped form a mosaic of different types of flammable vegetation.

The study area covers a large gradient of elevation from sea level to the subalpine ecosystems of the French Southern Alps (ca. $2500 \mathrm{~m}$ asl, up to 4101m). Mean annual 
74 precipitation ranged from 700 to $10001 \mathrm{~m}^{-2}$ year $^{-1}$ and mean maximum temperature ranged 75 from 18 to $23^{\circ} \mathrm{C}$ from the North to the South. The southern part of the study area, along the

\subsection{Data description}

\subsubsection{Descriptive factors}

Five types of descriptive factors of each "département" were taken into account to highlight different regions composed of "départements" that presented same trends in socioenvironmental characteristics:

(i) Land cover: The proportions of land cover types (in percentage) in each "département" were derived from the Corine land cover database 2006. Four types were compiled from the classes that could be involved in wildfires: forests (For), grasslands (Grass), shrublands (Shrub), and agricultural lands (Agri).

(ii) The densities of networks - roads and railways - were calculated by the Joint Research Centre (Ispra, Italy), from the Tele Atlas database. Regarding road density, only minor roads (R2_D) were taken into account in the analyses because most fires occurred along this type of road (Ganteaume and Long-Fournel 2015).

(iii) The climate variables, derived from the European Climate Assessment and Dataset, were built from the daily mean temperature and the daily precipitation amount per month since 1971. Two climate variables were taken into account: the number of dry months (Dry_Mth) calculated from the Gaussen index (Gaussen and Bagnouls 1952), 

1926) for spring, summer, and fall-winter; high index values indicated wetness.

100

101

102

103

104

105

106

107
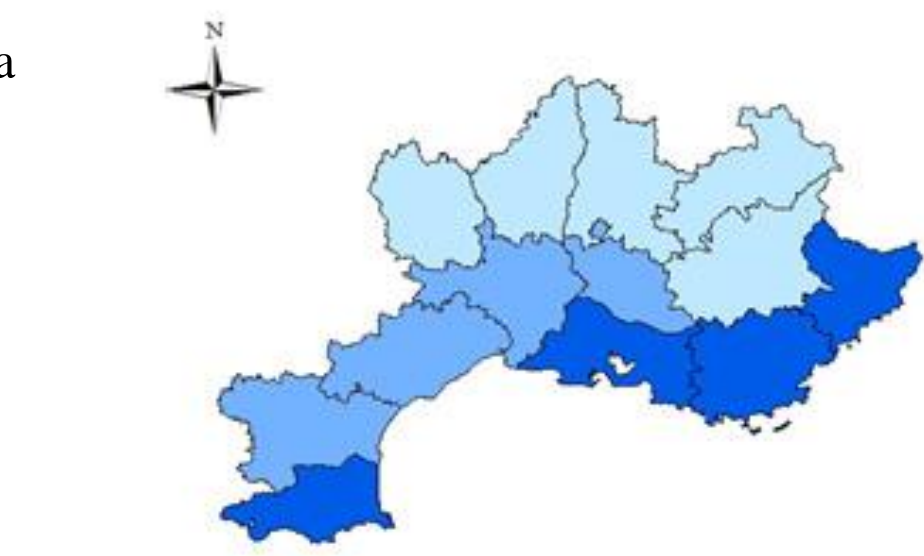

Region
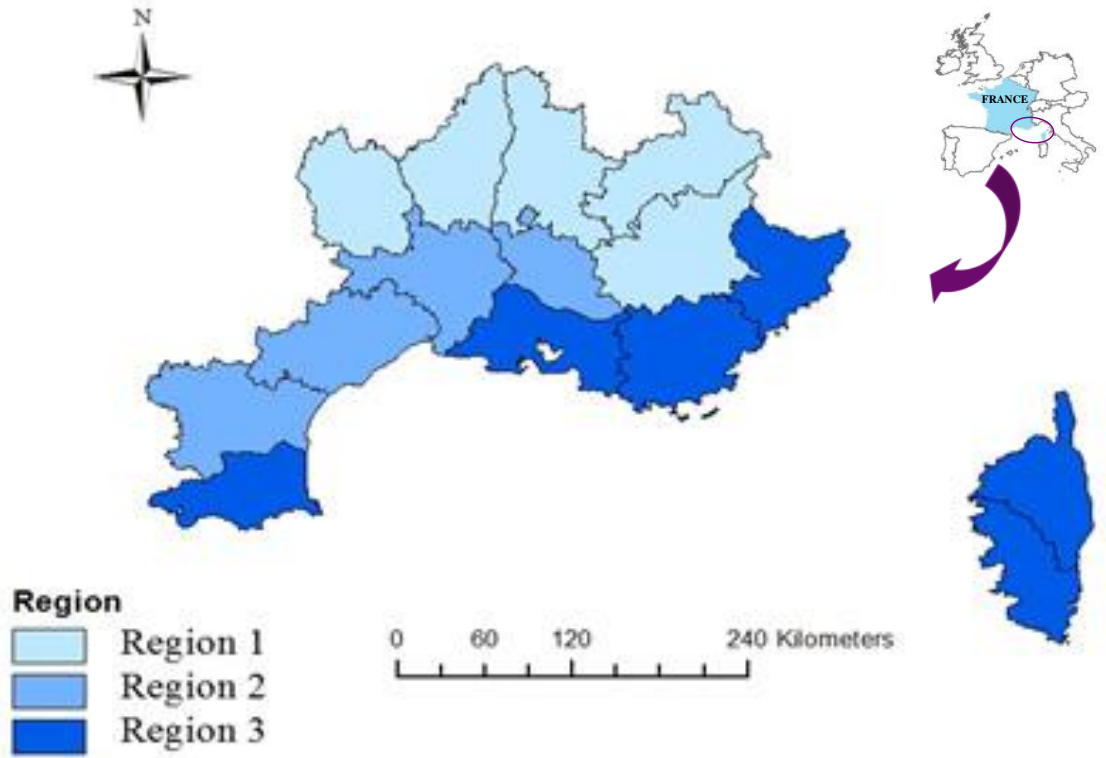

b

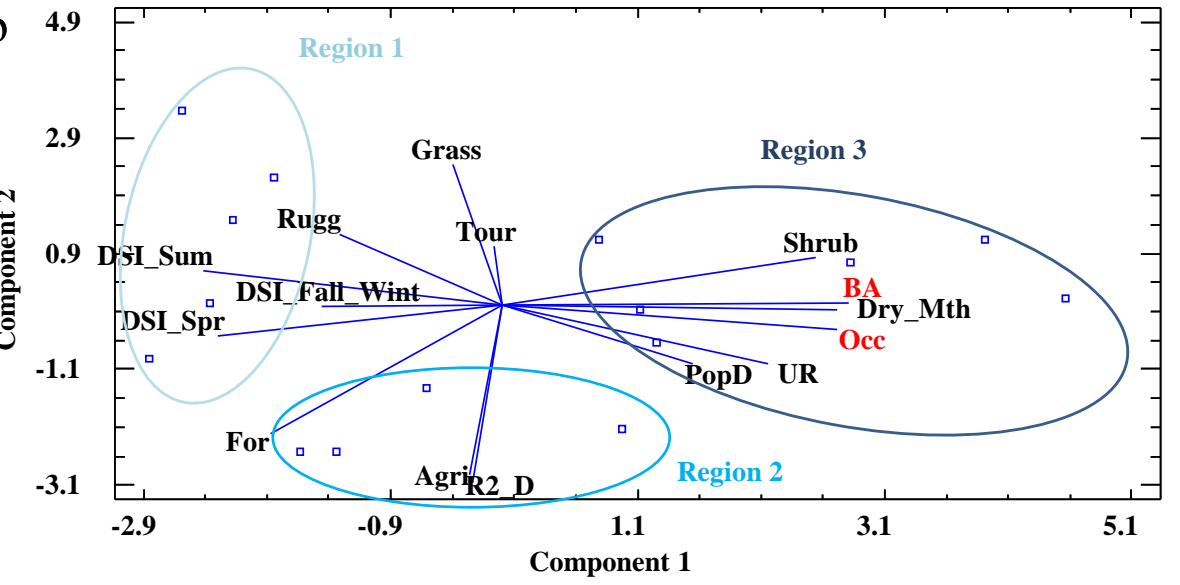

Figure 1: Map of the study area (southeastern France) showing the three regions (i.e. clusters) highlighted by Hierarchical Cluster Analyis (a) and their characteristics identified by Principal Component Analysis (b).

DSI: dry severity index, Sum: summer, Spr: spring, Wint: winter, Grass: grassland, For: forest, Agri: agicultural land, Shrub: shrubland, Rugg: ruggedness, Tour: tourist pressure, R2_D: density of secondary roads, Dry_Mth: number of dry month, PopD: population density, BA: burned area, Occ: fire occurrence. BD Carto®. 
(iv)The topographic variable was built from the global digital elevation model with a horizontal grid spacing of 30 arc seconds. This variable was the Topographic Ruggedness Index (Rugg) developed by Riley et al. (1999) to express the amount of elevation difference between adjacent cells of a digital elevation grid. In this work, only the index that corresponded to the most rugged terrain was used to characterize mountainous areas.

(v) Three socio-economic variables were derived from Eurostat databases: the mean population density (PopD, number of inhabitant per $\mathrm{km}^{2}$ ), the mean unemployment rate (UR, \%) and the mean number of overnight hotel stays used as a proxy for tourist pressure (Tour).

\subsubsection{Fire metrics}

In the current work, fire data come from the regional fire database Prométhée (www. promethee.com) that has recorded all wildfires that have occurred in the 15 "départements" of SE France, since 1973. Among the data available during the period 1973-2015, we compiled, for each ignition, the date (to determine at what season the ignition occurred) and place (to determine in which "département" the ignition occurred), the burned area, as well as the level of certainty (known and unknown) and the nature (when it was known) of the fire cause. In this database, fire ignitions are located on the basis of a $2 \mathrm{~km} * 2 \mathrm{~km}$ grid reference (used by the firefighting services for approximating the location of the fire event); this georeferencing system was used for the GIS analyses.

The total number of fires (defined as the fire occurrence) and the total burned area recorded in each "département" during the 1973-2015 period were taken into account as 
132 dependent variables in the statistical analyses. Fires were also analyzed according to three size

133 classes (small: $\mathrm{S} 1<1$ ha, moderate: 1 ha $\leq \mathrm{S} 2<100$ ha, and large $\mathrm{S} 3 \geq 100$ ha).

136 The database Prométhée identifies five main classes of causes (one-digit codes) which are

137 defined in Camia et al. (2013): (i) natural (any wildfire caused by natural origin, with no

138 human involvement in any way; in the study area, only lightning ignitions belong to this

139 class), (ii) accidental (wildfires unintentionally and indirectly caused by humans, without use

140 of fire, connected neither to will nor to negligence, rather to fate; this included fires due to

141 structures, such as power lines, railways, vehicles, or garbage dumps), (iii) deliberate (wildfire

142 intentionally caused by humans with the use of fire for different motives, such as conflict,

143 interest, or pyromania), (iv) negligence during professional works (wildfire unintentionally

144 caused by humans using fire or glowing objects during professional activities, not connected

145 to fate), and (v) negligence during leisure activities (wildfire unintentionally caused by

146 humans using fire or glowing object during recreation, not connected to fate). Each class was

147 divided into different sub-classes of two-digit, and three-digit codes (except for the natural

148 cause) for the most detailed causes. In this current work, these two sub-classes were merged

149 because of the low number of fires due to the causes identified with three-digit codes (Table $1501)$.

\subsection{Statistical and spatial analyses}

153 The identification of homogeneous regions from the 15 "départements" of SE France was

154 performed using Hierarchical Cluster Analysis (Ward method, based on squared Euclidian 155 distance; R 2.15-0, package ADE-4 1.5-1, R Development Core Team 2005), using the 156 different descriptive factors (socio-environmental characteristics) of each "département". This 
analysis was used to group the "départements" into clusters (hereafter called regions), in such

158 a way that two "départements" from the same region were more similar than two

159 "départements" from different regions, regarding these socio-environmental characteristics.

160 To highlight what were the main characteristics of each region identified, Principal

161 Component Analysis was performed taking into account the socio-environmental factors as

162 well as the total fire occurrence and burned area of each "département" (Statgraphics

163 Centurion XV, StatPoint Technologies).

164 Representing wildfire incidents as points on a map made it difficult to distinguish

165 "clusters" of ignitions, because the points overlapped. To address this limitation, we used the

166 Kernel density method to highlight, for each main cause, the hotpots of ignitions (and of large

167 fire ignitions) throughout the study area. This method is a non-parametric statistical technique

168 that was aimed at producing a smooth density surface; thus, accounting for the uncertainty

169 regarding the accuracy of the original ignition location. In assigning a buffer area around each

170 spatial fire ignition, a normal distribution of density surfaces (based on the number of

171 ignitions per point) was created over each point. When multiple buffers overlapped, the kernel

172 density values were combined to derive the ignition density surface. This provided a much

173 clearer illustration of where the ignitions were the most frequent (hotspot) and allowed the use

174 of a straightforward and quantitative value (number of ignitions per square kilometer). For

175 this analysis, we used the Spatial Analyst Extension of ArcGIS 10.2 whose kernel function

176 was based on Silverman's quartic kernel function (Silverman 1986). However, spatial analyst

177 provides a search radius algorithm based on the distance between ignitions giving a too

178 smoothed result. In order to obtain sharper density changes, we empirically chose a shorter

179 search radius (6000 m-radius, including 28 possible locations) according to the initial grid of

180 the Prométhée database. A 50m-resolution was chosen for the output raster. The spatial 
181 182 period.

analysis was based on the total number of fires with known causes during the 1973-2015

Using Statgraphics Centurion XV software, multi-factor ANOVAs were performed to assess the impact of region, cause, and season on the fire metrics. In addition to the tests of overall significance, the Least Significance Difference (LSD) test was used to check for significant differences between the different means. A significant relationship between the variables was assumed when the p-value was $\leq 0.05$. When the distribution of data did not follow the expected parametric pattern, data were log-transformed. When the three parameters (region, season, cause) interacted, regression trees were used to refine the results obtained and to give probabilities of fire occurrence and predicted mean burned area (analyses run only on fires $\geq 1$ ha, using R 2.15-0, package rpart, R Development Core Team, 2005).

\section{Results}

Hierarchical cluster analysis allowed the 15 "départements" to be grouped into three homogeneous regions (clusters) according to the socio-environmental factors. Principal Component Analysis performed on these explanatory factors revealed the main characteristics of each region (Fig. 1). Region 1 was mainly characterized by climatic (wettest climate conditions) and topographic trends (highest elevation), as this region is comprised of the "départements" located in the northern part of the study area, most of them being mainly mountainous. Trends in land cover (high proportion of forest and agricultural lands) and in network density (high density of secondary roads) best characterized region 2 , which is more central in the study area, whereas socio-economic (high unemployment rate and population density), climatic (driest climate conditions), and land cover (high proportion of shrubland) 
trends better characterized region 3, this densely populated region being located mainly in the

206 southeastern part of the study area (except for the "département" Pyrénées-orientales which is 207 located at the western part of the study area). If the total number of fires and burned area of 208 each "département" were added to the analysis, the composition of the three regions would 209 not change.

\subsection{Characterizing the spatial and seasonal variation of fire metrics}

212 In total, during the 1973-2015 period, 106,904 fires occurred and burned 884,492 ha in the study area, mostly in summer.

Regarding the spatial variation of fire metrics, region 3 was the area the most impacted by wildfires, in terms of occurrence and burned area (68\% of the total occurrence and $73 \%$ of 216 the total burned area) in contrast to regions 1 and $2(13 \%$ and $19 \%$ of the total occurrence and $21710 \%$ and $16 \%$ of the total burned area) (Table 2). Fires of small (S1 $<1$ ha) and moderate (1 218 ha $\leq \mathrm{S} 2<100 \mathrm{ha}$ ) sizes were the most frequent in regions 1 and 2 (between 47 and $51 \%$ ) 219 whereas, in region 3, most fires were small $(\mathrm{S} 1=69 \%)$. The proportion of large fires ( $\mathrm{S} 3 \geq 100$ 220 ha) was the lowest regardless of the region (less than $1.2 \%$ of the fires), but these fires greatly 221 affected region 3 in terms of burned area (78\% of the total burned area in region $3 v s 48 \%$ and $22256 \%$ in regions 1 and 2, respectively).

Regarding the seasonal variation of fire metrics, in region 1, fires mainly occurred in summer and winter whereas they were concentrated mostly during the summer season in region 3 (57\% of occurrence and 83\% of burned area). Regions 2 and 3 presented higher proportion of autumn fires than region $1(9 \%$ vs $6 \%)$ but the proportion of area burned in fall was higher in region 1 (9\% vs 7 and 5\%). Region 1 also presented the highest occurrence 228 (20\%) and burned area (18\%) due to spring fires (Table 2). In each region, fire occurrence and 
Table 1: List of the fire causes and motives recorded in the study area, their occurrence and burned area (in \%), as well as their mean burned area

230 (in ha) according to the regional fire database Prométhée (in bold: main cause > 5\%).

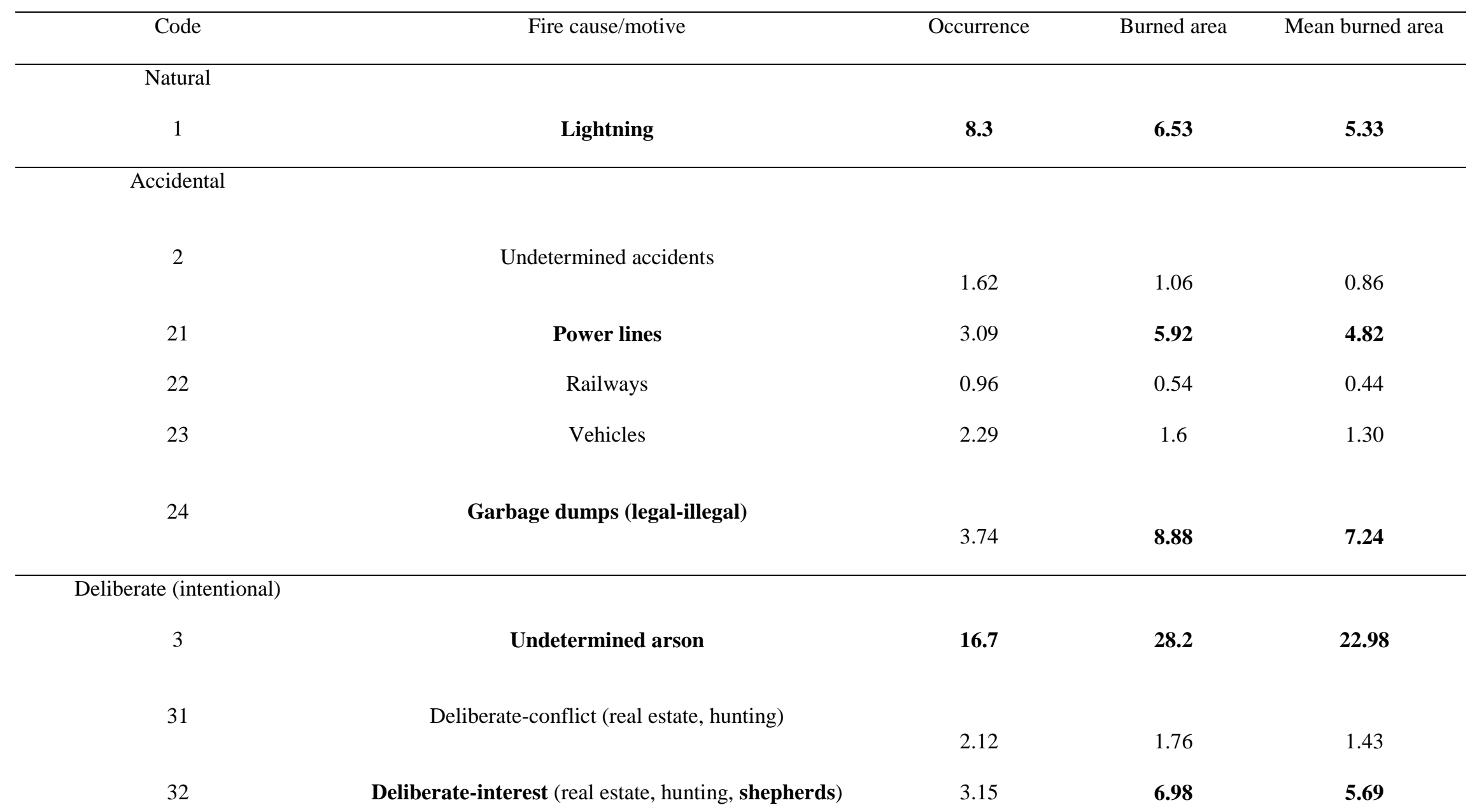


Negligence in professional works

\begin{tabular}{|c|c|c|c|c|}
\hline 4 & Undetermined professional works & 1.41 & 0.83 & 0.67 \\
\hline 41 & Forestry works & 11 & 5.97 & 4.87 \\
\hline 42 & Agricultural works & 14.7 & 9.17 & 7.48 \\
\hline 43 & Industrial works & 0.9 & 0.27 & 0.22 \\
\hline \multicolumn{5}{|c|}{ Negligence in recreation } \\
\hline 5 & Undetermined leisure activities & 2.79 & 0.93 & 0.76 \\
\hline 51 & Private works & 9.37 & 2.51 & 2.05 \\
\hline \multicolumn{5}{|l|}{52} \\
\hline 53 & Glowing items (cigarettes, distress rocket, hot ashes) & 4.48 & 6.97 & 5.68 \\
\hline
\end{tabular}


231 burned area were significantly affected by season $\left(\mathrm{Chi}^{2}=1955.18, \mathrm{p}<0.0001 ; \mathrm{Chi}^{2}=71894.96\right.$, $232 \mathrm{p}<0.0001$, respectively).

234 Table 2: Characteristics of the study area and of regions in terms of fire metrics (size $1<1$ ha; $2351 \leq$ size $2<100$ ha, size $3 \geq 100$ ha).

236 Known/unknown fire means fire whose cause is known/unknown.

\begin{tabular}{|c|c|c|c|c|}
\hline Study area and Fire metrics & Region 1 & Region 2 & Region 3 & Study area \\
\hline Surface area (ha) & 2996126 & 2204647 & 2833867 & 8034640 \\
\hline Total number of fires & 13629 & 20390 & 73078 & 107097 \\
\hline$\%$ occurrence in SE France & 12.7 & 19 & 68.2 & \\
\hline$\%$ fall occurrence & 5.8 & 9.4 & 9.3 & 8.9 \\
\hline$\%$ winter occurrence & 31.8 & 20.3 & 17 & 19.5 \\
\hline$\%$ spring occurrence & 19.9 & 16.7 & 16.8 & 17.2 \\
\hline \% summer occurrence & 42.4 & 53.6 & 56.9 & 54.4 \\
\hline Total burned area (ha) & 92006 & 141966.8 & 650518.8 & 884491.5 \\
\hline$\%$ burned area & 10.4 & 16.0 & 75.5 & \\
\hline$\%$ fall burned area & 9.0 & 6.7 & 4.6 & 5.4 \\
\hline$\%$ winter burned area & 27.1 & 9.2 & 6.6 & 9.1 \\
\hline$\%$ spring burned area & 17.8 & 10.0 & 5.7 & 7.7 \\
\hline$\%$ summer burned area & 46.1 & 74.1 & 83.1 & 77.8 \\
\hline$\%$ fires size 1 & 47.4 & 50.7 & 68.8 & 62.6 \\
\hline$\%$ fires size 2 & 51.5 & 48.1 & 30.0 & 36.2 \\
\hline$\%$ fires size 3 & 1.15 & 1.16 & 1.22 & 1.20 \\
\hline$\%$ known fires & 53.6 & 45.8 & 33.8 & 33.7 \\
\hline$\%$ unknown fires & 46.4 & 52.2 & 66.2 & 66.3 \\
\hline$\%$ area burned by known fires & 55.7 & 52.1 & 38.1 & 28.1 \\
\hline$\%$ area burned by unknown fires & 44.3 & 47.9 & 61.9 & 71.9 \\
\hline
\end{tabular}


239 In SE France, during the 1973-2015 period, knowledge of fire causes was poor; only 33.7\% of 240 the total number of fires had a known cause that corresponded to 35,960 fires and 243,523 ha 241 burned but this knowledge varied spatially in the study area. Indeed, the nature of the fire 242 causes was better known in region 1, in which $54 \%$ of the fires had known causes than in 243 regions $2(46 \%)$ and $3(34 \%)$ (Table 2).

For the study area and regarding both fire metrics, the main fire causes taken into account in the analyses are presented in table 1. It is worth noting that the deliberate fires due to interest (cause 32) mainly involved shepherds (hunting activities and real estate were the other motives of these deliberate fires) and the unintentional fires due to glowing items (cause 53) were mainly due to cigarette butts. Lightning (cause 1), negligence during forestry and private works (causes 41 and 51, respectively) were the most frequent causes of small fires 250 (S1), while negligence during agricultural works (cause 42) was the most frequent cause of fires of intermediate size (S2). Undetermined arson caused most large fires (S3, $0.24 \%$ of the total number of fires), even if this fire size was the least represented in the study area. Globally, undetermined arson (18\%), forestry and agricultural works (12\% and 16\%, 254 respectively) accounted for the highest occurrence and undetermined arson (29\%) resulted in 255 the largest burned areas.

At the level of the study area, hotspots of fire ignitions due to five of the main causes were highlighted by kernel density and large fire ignitions were pinpointed on the maps thus obtained (Fig. 2). Hotspots of ignitions due to undetermined arson (Fig. 2a) which was the cause the most densely aggregated were mainly located in the southern part of the study area

260 (corresponding to region 3 in which these fires were the most frequent: 19\%; fig. 3c). Clusters of large fires (up to two large fires) were situated in the southeastern area. Hotspots of 
262 ignitions due to professional (forestry and agriculture; fig. 2b, c) and private works (Fig. 2d) 263 were mainly located in the northwestern and southeastern part of the study area; large 264 agricultural fires being more aggregated in the western area.

On the whole, the different fire metrics varied spatially. For instance, fires due to 266 professional activities were the most frequent in region 1 (cause 41: $16 \%$ and cause 42: 23\%; 267 fig. 3a) and in region 2 (agricultural fires: 18\%; fig. 3b). Most burned area was due to 268 undetermined arson and agricultural works in regions 1 (17\% and 21\%, respectively; fig. 3a) 269 and 2 (26\% and 14\%, respectively; fig. $3 b)$ as well as to undetermined arson, mainly in region $2703(32 \%$, fig. 3c). It is worth noting that, regarding the mean burned area, the largest fires were 271 due to undetermined arson (18 ha) in region 1, to railways in region 2 (11 ha), and to garbage 272 dumps in region 3 (14 ha). Hotspots of natural ignitions, less densely aggregated than those 273 due to the previous causes (up to 0.97 fires per $\mathrm{km}^{2}$ instead of up to 2.1 fires per $\mathrm{km}^{2}$ ), were 274 spread throughout the study area (Fig. 2e). However, the occurrence and area burned by these 275 fires were higher in region 1 (Fig. 3a) because the proportions were calculated on the total 276 number of fires of each region. Lightning ignitions spatially varied from $6 \%$ and $7 \%$ of 277 occurrence in regions 2 and 3 to $13 \%$ of occurrence in region 1, and from $4 \%$ of burned area 278 in region 2 to $10 \%$ of burned area in region 1 . Their mean size was larger in region 3 than in 279 the other regions ( 7 ha $v s 4$ and 1 ha in regions 1 and 2, respectively).

Regarding the seasonal variation of fires, our results highlighted the fact that most causes presented a seasonal trend that could, however, differ between the causes (Fig. 4). 282 Fires due to power lines entailed the largest total burned area in fall (due to their larger size at 283 this season), despite their low occurrence (Fig. 4a). On the whole, most causes mainly 284 occurred and had more severe effect in summer. Some, such as undetermined arson, presented 285 high fire metrics most of the year (except in winter), with maximum values in summer: $24 \%$ 286 of occurrence and $34 \%$ of total area burned by these deliberate fires at this season (Fig. 4b), 
but the largest mean burned area in summer being due to garbage dumps (22 ha). Private

288 works presented a higher occurrence in spring and winter (Fig. 4c, d) but their mean burned

289 area was small resulting in a smaller total burned area, regardless of the season. Accordingly,

290 fires due forestry and agricultural works were small but very frequent nearly year-round

291 (except in summer), resulting in a large total burned area (mostly in winter, fig. 4d). Other

292 fires, such as natural fires, were frequent during one particular season (i.e. in summer for

293 natural fires; fig. 4b) but presented a larger total burned area during a different season (i.e. in

294 spring for natural fires; fig. 4c). Moreover, some causes were less frequent but presented

295 larger fires at a particular season resulting in a large total burned area (garbage dumps and

296 glowing items in summer and spring respectively, and power lines in fall). Finally, others,

297 such as pyromania and recreational activities, were neither frequent nor large regardless of the 298 season (Fig. 4).

On the whole, regardless of region and season, fires due to railways, vehicles, deliberate-conflict, negligence during industrial works, rekindle, as well as unidentified accidents and negligence were the least frequent and severe $(<5 \%$; table 1$)$.

\subsection{Effects of interactions between factors on fire metrics}

304 Region, season, and fire cause were the three factors that significantly affected both fire 305 occurrence and burned area. Region was the most important factor for fire occurrence, and 306 season most impacted burned area (Multi-factor ANOVA; table 3). In terms of fire 307 occurrence, the trends highlighted in figure 5 showed that this variable significantly decreased 308 from region 3 to region 1, and from undetermined arson (as well as agricultural and forestry 309 works) to the other fire causes. On the whole, this metric was, maximum in summer and 310 minimum in fall (in between, decreasing from spring to winter). In terms of fire severity (Fig. 311 6), the total burned area was significantly the largest in region 3 and the largest areas were 

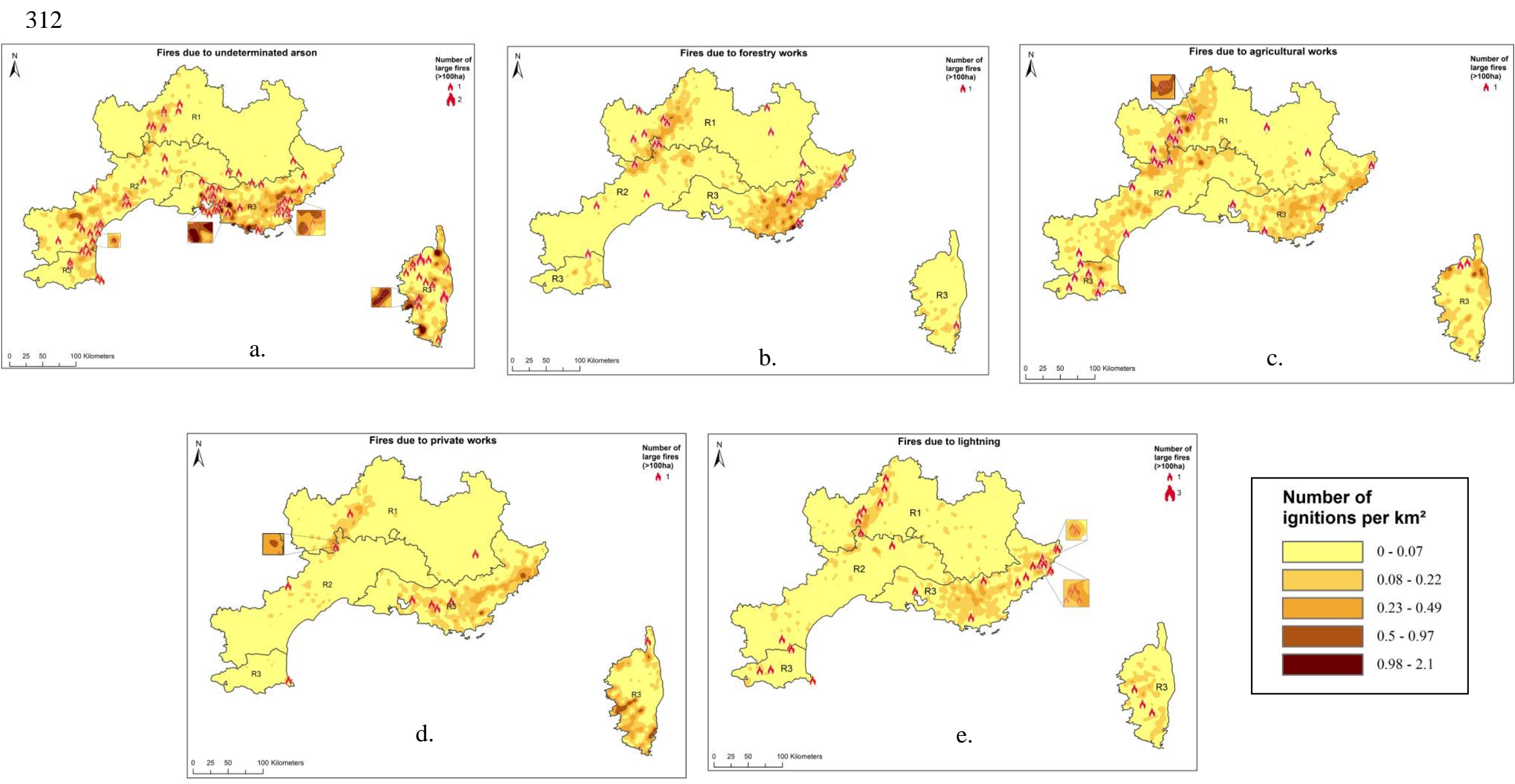

Figure 2: Hotspots of total fire ignitions and locations of large fire ignitions of five of the main fire causes in SE France (BD Carto®): a. undetermined arson, b. forestry works, c. agricultural works, d. private works, and e. lightning. 


\section{a. \\ Region 1: occurrence vs burned area according to fire causes}

313

314

315

316

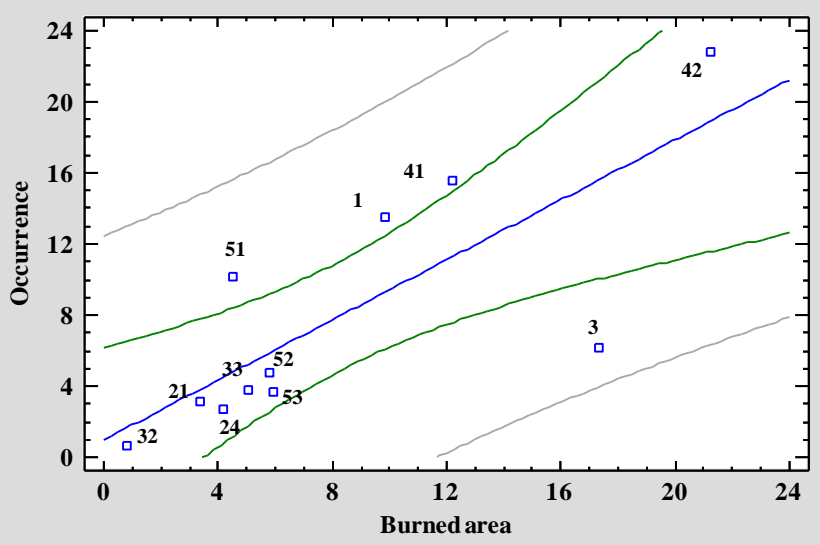

b.

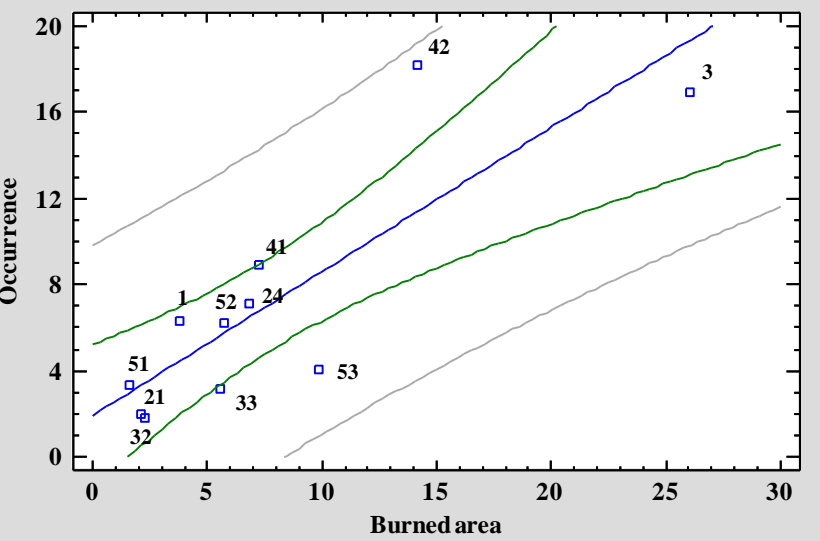

Figure 3: Spatial occurrence and total burned area (in percentage) according to the main fire causes: a. region $1, \mathrm{~b}$. region 2, c. region 3 (For the codes of each cause see table 1. Causes 2, 22, 23, 31, 4, 43, 44, and 5 were not shown because of their too low impact in terms of both fire metrics). 
Fall: occurrence vs burned area according to fire causes

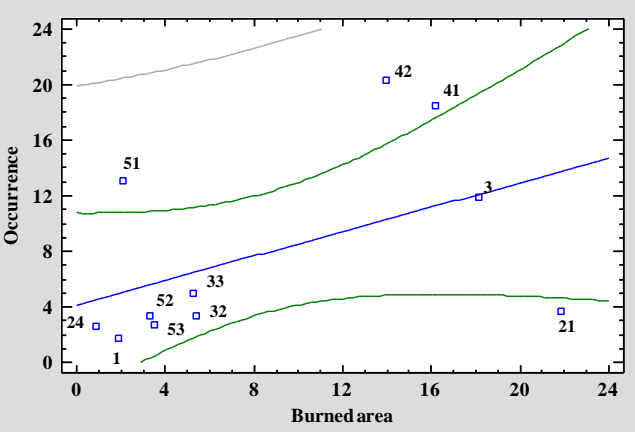

b.

Summer: occurrence vs burned area according to fire causes

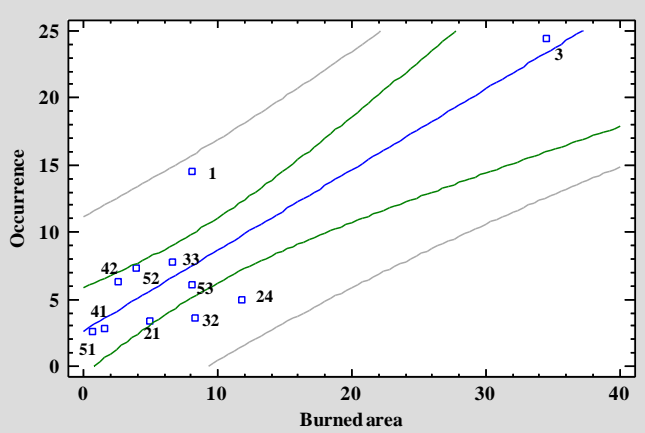

c.
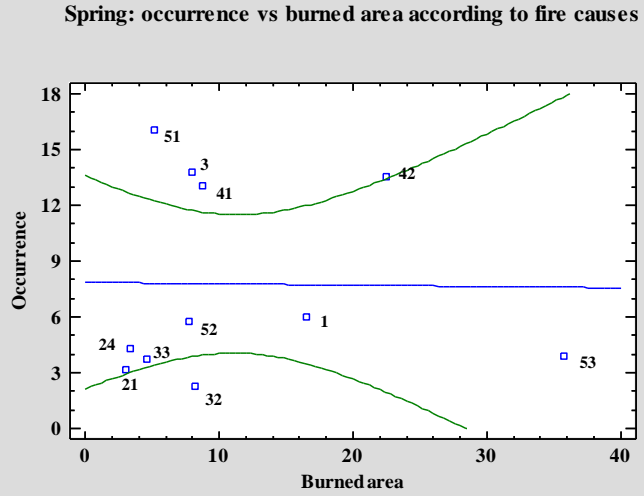

d.

Winter: occurrence vs burned area according to fire causes

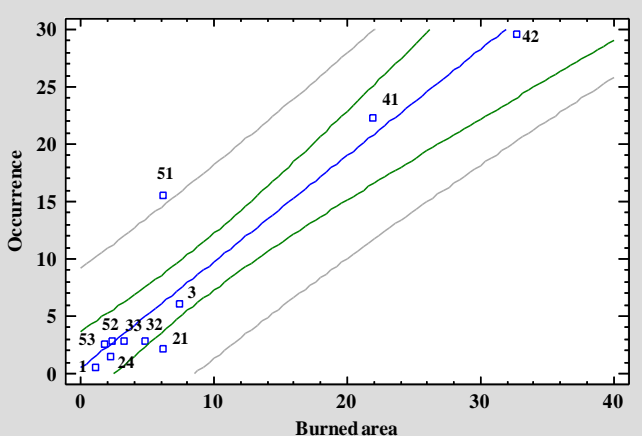

Figure 4: Seasonal occurrence and total burned area (in percentage) accorumg to me mann tire causes: a. lall, o. winter, c. spring, d. summer (For the codes of each cause see table 1 . Causes $2,22,23,31,4,43,44$, and 5 were not shown because of their too low impact in terms of both fire metrics). 
340 burned in summer, mostly because of fires due to undetermined arson. Moreover, fires were

341 globally more severe in winter and in spring (mostly due to forestry and agriculture) than in 342 fall.

343 However, the interactions between factors taken two by two had a significant impact on the 344 fire metrics and the strongest interaction occurred between season and cause (Table 3). 345 Indeed, both occurrence and total area burned by fires due to deliberate-interest, forestry, 346 agricultural and private works were higher and larger in winter than in summer (Fig. 5a and 347 6a) contrary to the general trend. Moreover, as shown by the interaction cause-region, 348 agricultural works did not follow the general spatial trend (described above), especially 349 regarding the burned area which was not the largest in summer (Fig. 6c). The interaction 350 highlighted between region and season showed that occurrence and burned area in region 1 351 were higher and larger in winter than in spring (Fig. 5a and 6a).

353 Table 3: Multi-factor ANOVA performed on fire occurrence and total burned area (log354 transformed) according to cause, region, and season (F: Fisher test, Ddl: degrees of freedom).

Occurrence Burned area

\begin{tabular}{lcccccc}
\hline & Ddl & $F$ & Probability & Ddl & Probability \\
\hline Cause & 15 & 6.44 & $\mathrm{p}<0.0001$ & 15 & 11.21 & $\mathrm{p}<0.0001$ \\
Region & 2 & 288.69 & $\mathrm{p}<0.0001$ & 2 & 43.59 & $\mathrm{p}<0.0001$ \\
Season & 3 & 163.97 & $\mathrm{p}<0.0001$ & 3 & 48.98 & $\mathrm{p}<0.0001$
\end{tabular}

\section{Interactions}

$\begin{array}{lcccccc}\text { Cause/Region } & 30 & 9.43 & \mathrm{p}<0.0001 & 30 & 3.81 & \mathrm{p}<0.0001 \\ \text { Cause/Season } & 45 & 15.13 & \mathrm{p}<0.0001 & 45 & 3.88 & \mathrm{p}<0.0001 \\ \text { Region/season } & 6 & 8.05 & \mathrm{p}<0.0001 & 6 & 2.77 & \mathrm{p}=0.0192\end{array}$


Interaction Region-Season for fire occurrence

\section{Interaction Season-Cause for fire occurrence}

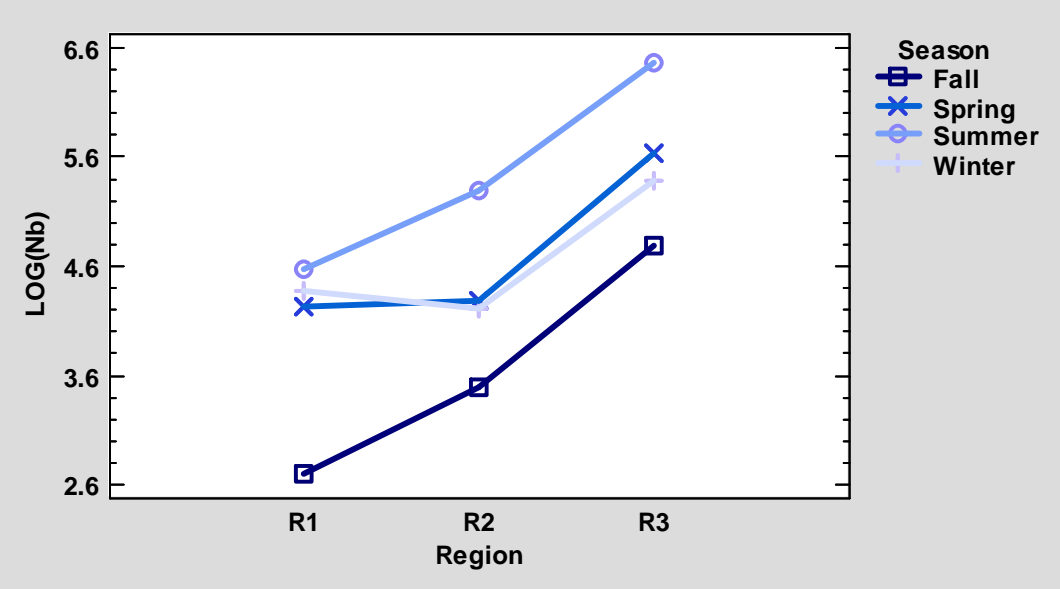


377 Multi-factor ANOVA, Nb: number of fires, F: Fall, Sp: Spring, Su: Summer, W: Winter, R1:

378 Region 1, R2: Region 2, R3: Region 3 (For the codes of each cause see Table 1. Causes 2, 22,

$37923,31,4,43,44$ and 5 were not taken into account in the analyses because of their too low 380 impact in terms of fire occurrence).

381

382 
Interaction Region-Seas on for burned area

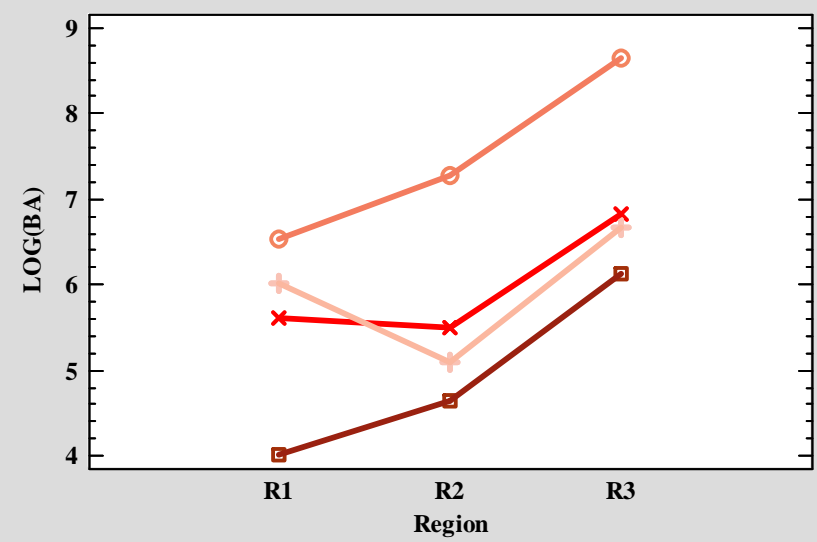

Season - Fall $\approx$ Spring

Summer

Winter

Interaction Season-Cause for burned area

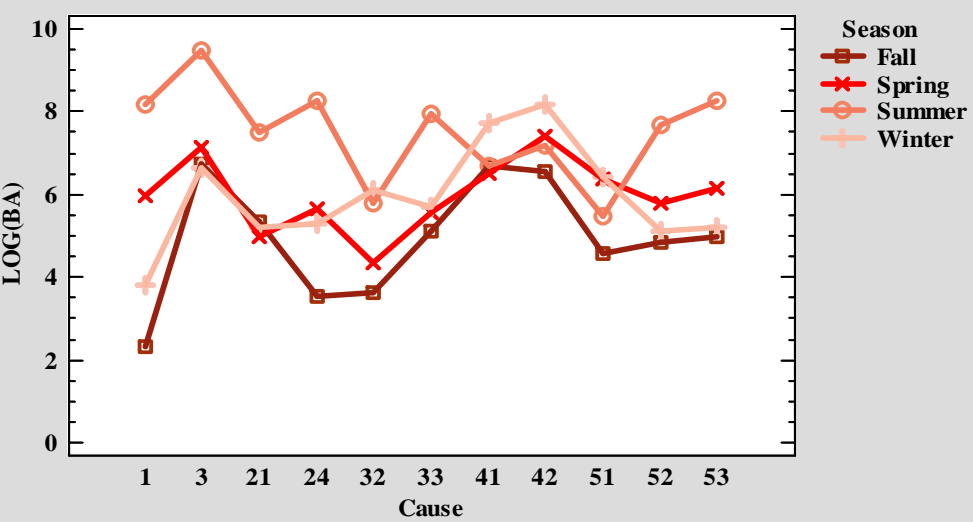

Interaction Region-Cause for burned area

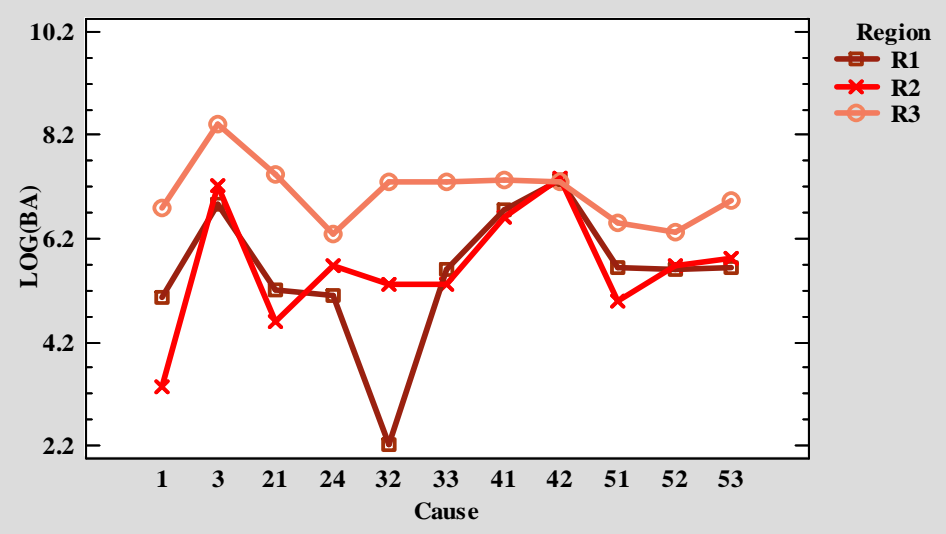

403 Figure 6: Interactions between fire cause, region, and season regarding burned area. 
404 Multi-factor ANOVA, BA: Burned area, F: Fall, Sp: Spring, Su: Summer, W: Winter, R1:

405 Region 1, R2: Region 2, R3: Region 3 (For the codes of each cause see table 1. Causes 2, 22,

$40623,31,4,43,44$ and 5 were not taken into account in the analyses because of their too low 407 impact in terms of burned area).

408 
The regression tree analyses ${ }^{1}$ performed on fire occurrence and mean burned area

410 simultaneously took into account the three factors cause, region and season (Table 4).

411 Regarding fire occurrence, these analyses showed that, for most causes, the number of fires

412 decreased from summer to the other seasons and was higher in region 3, which was consistent

413 with the previous results. However, because of the interactions between factors, some causes

414 did not follow this general trend: fires due to lightning and to recreational activities were more

415 frequent in summer in region 1, as were fires due to power lines in fall in region 3 (an 416 example of output data produced by the regression tree analysis run on cause 21 is given in 417 fig. 7a), to forestry and agricultural works in winter in regions 1 and 2, and to private works in 418 spring in region 3. Except for power lines and deliberate-interest, season better predicted the 419 fire occurrence (contrary to the results of ANOVAs) and showed different patterns according 420 to the cause. Some causes opposed summer to the other seasons regardless of the region: 421 lightning, garbage dumps, undetermined arson, and pyromania presented a higher occurrence 422 at this season contrary to forestry and agricultural works (lower occurrence in summer). 423 Others opposed spring and summer to winter and fall: fires due to private works were more 424 frequent in fall-winter contrary to fires due to recreational activities that were more frequent 425 summer. In contrast, region was the best predictor of fire occurrence due to power lines and to 426 deliberate-interest, opposing region 3 to regions 1 and 2, as shown for power lines in figure 427 7a. The number of splits required to obtain the highest occurrence varied according to the 428 cause, ranging from two splits for causes $1,32,33,21$, and 24 to five splits for cause 51 . In 429 these analyses, the accuracy was always higher than 0.90 (Table 4).

Regarding mean burned area, regression tree analyses predicted, for each cause, the 431 mean area burned according to the two other factors. Results showed that season was the best 432 predictor of mean burned area regardless of fire causes. This fire metric decreased from

\footnotetext{
${ }^{1}$ Analyses run only on fires $\geq 1$ ha.
} 
433 summer to the other seasons (an example of output data produced by the regression tree 434 analysis run on cause 3 is given in figure $7 b$ ), except for power lines and recreational 435 activities which caused larger fires in fall in regions 3 and 2 respectively, as well as for 436 pyromania (larger fires in spring) in region 3 and for agricultural works (larger fires in spring) 437 in region 1 (Table 4). The largest fires predicted by the regression trees occurred in region 3 438 (as shown, for instance, for fires due to undetermined arson in figure $7 \mathrm{~b}$ ), except for 439 agricultural works and recreational activities (larger fires in regions 1 and 2, respectively) 440 (Table 4). The number of splits required to obtain the largest predicted mean burned area 441 varied according to the cause, ranging from three splits (causes 1, 3, 32, 24, 41, 51, and 53) to 442 six splits (cause 42). In these analyses, the accuracy was always higher than 0.98 (Table 4). Except for power lines, undetermined arson, deliberate-interest, and glowing items, the 444 most impacted region and season, in terms of fire occurrence, differed from those that 445 presented the largest mean burned area. For instance, fires due to garbage dumps mostly 446 occurred in summer in region 2 but they were the most severe at the same season in region 3 447 (Table 4).

\section{Discussion}

\subsection{Spatial and seasonal variation of fire metrics and causes}

452 The spatial analysis (Kernel density) allowed us to highlight hotspots of ignitions due to five 453 of the main fire causes in the study area. If natural fires were not heavily aggregated, the 454 locations of highly aggregated ignitions due to the other causes, especially undetermined 455 arson, were precisely pinpointed mainly in the southern part of the area. Gonzalez-Olabarria 456 et al. (2012), using the same method, also showed that, in Catalonia (Spain), fire ignitions 
Table 4: Probability of fire occurrence (in \%) and mean burned area (in ha) predicted by regression trees according to cause, region, and season.

Regional total and mean burned area are also given for each cause.

Analyses were run on the dataset of fires $\geq 1$ ha. In bold: highest values for each cause; in italic: highest value per region; accuracy: relative error; n: number of fires $\geq 1$ ha, BA: burned area, Mean BA=total BA/occurrence. For the codes of cause see table 1. Causes 2, 22, 23, 31, 4, 43,

44 and 5 were not taken into account in the analyses because of their too low impact in terms of both fire metrics.

\begin{tabular}{cccccccccccccc}
\hline Season/Causes & 1 & 21 & 24 & 3 & 32 & 33 & 41 & 42 & 51 & 52 & 53 \\
$(\mathrm{n})$ & 650 & 438 & 607 & 1740 & 526 & 634 & 1676 & 2723 & 727 & 551 & 553 \\
\hline
\end{tabular}

\begin{tabular}{|c|c|c|c|c|c|c|c|c|c|c|c|c|}
\hline Fire occurren & & & & & & & & & & & & \\
\hline \multirow[t]{4}{*}{ Region 1} & Fall & 2.7 & 6.0 & 1.1 & 7.1 & 0.0 & 2.7 & 24.0 & 30.0 & 8.8 & 4.9 & 4.4 \\
\hline & Winter & 0.3 & 1.4 & 0.6 & 3.2 & 1.2 & 2.1 & 26.0 & 39.0 & 11.0 & 2.2 & 2.6 \\
\hline & Spring & 6.2 & 4.1 & 1.8 & 7.7 & 0.5 & 2.1 & 20.0 & 31.0 & 7.3 & 3.3 & 4.2 \\
\hline & Summer & 24.0 & 4.4 & 7.8 & 11.0 & 0.1 & 6.8 & 5.1 & 13.0 & 1.6 & 8.1 & 4.9 \\
\hline \multirow[t]{3}{*}{ Region 2} & Fall & 0.0 & 3.2 & 5.4 & 11.0 & 3.5 & 1.1 & 16.0 & 38.0 & 2.4 & 1.9 & 3.2 \\
\hline & Winter & 0.0 & 0.6 & 1.8 & 7.0 & 3.5 & 1.9 & 23.0 & 42.0 & 5.0 & 1.2 & 1.6 \\
\hline & Spring & 3.2 & 3.8 & 9.6 & 9.9 & 3.1 & 1.9 & 15.0 & 25.0 & 4.8 & 6.7 & 3.2 \\
\hline
\end{tabular}




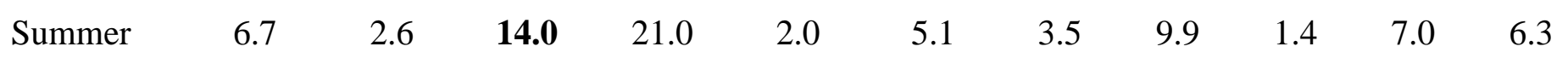

\begin{tabular}{|c|c|c|c|c|c|c|c|c|c|c|c|c|}
\hline \multirow[t]{4}{*}{ Region 3} & Fall & 2.7 & 6.3 & 2.2 & 12.0 & 7.1 & 7.6 & 19.0 & 19.0 & 8.0 & 3.2 & 2.3 \\
\hline & Winter & 1.0 & 4.7 & 1.7 & 7.9 & 6.8 & 3.6 & 22.0 & 30.0 & 10.0 & 3.5 & 3.3 \\
\hline & Spring & 3.6 & 4.5 & 3.7 & 14.0 & 5.2 & 5.8 & 14.0 & 14.0 & 13.0 & 4.9 & 5.4 \\
\hline & Summer & 7.9 & 4.4 & 4.5 & 27.0 & 8.3 & 10.0 & 2.5 & 7.7 & 1.7 & 5.1 & 6.8 \\
\hline Accuracy & & 0.928 & 0.993 & 0.959 & 0.942 & 0.979 & 0.981 & 0.931 & 0.905 & 0.967 & 0.99 & 0.992 \\
\hline
\end{tabular}

Mean burned area

\begin{tabular}{ccccccccccccc}
\hline Region 1 & Fall & 1.3 & 6.2 & 6.0 & 46.0 & 0.0 & 27.0 & 9.9 & 9.0 & 6.2 & 5.2 & 4.6 \\
& Winter & 6.4 & 3.2 & 34.0 & 13.0 & 18.0 & 17.0 & 8.5 & 8.3 & 5.9 & 6.2 & 4.8 \\
& Spring & 24.0 & 8.8 & 11.0 & 7.6 & 2.3 & 3.8 & 6.5 & $\mathbf{1 3 . 0}$ & 12.0 & 13.0 & 19.0 \\
& Summer & 18.0 & 26.0 & 19.0 & 59.0 & 4.0 & 22.0 & 10.0 & 7.9 & 6.5 & 26.0 & 40.0 \\
& Total & 3911.7 & 1333.8 & 1684.6 & 6991.9 & 316.7 & 2013.6 & 4851.4 & 8471.9 & 1717.4 & 2321.6 & 2391.4 \\
& Mean & 15.04 & 14.19 & 18.93 & 35.13 & 15.08 & 18.82 & 8.31 & 9.21 & 7.04 & 17.72 & 20.98 \\
& Fall & 0.0 & 2.5 & 4.7 & 11.0 & 7.6 & 11.0 & 13.0 & 9.6 & 3.8 & $\mathbf{5 8 . 0}$ & 19.0 \\
& Winter & 2.0 & 6.2 & 3.5 & 5.9 & 6.7 & 5.2 & 5.1 & 4.9 & 5.7 & 2.9 & 5.6 \\
& Spring & 3.0 & 3.2 & 5.6 & 27.0 & 6.4 & 13.0 & 3.6 & 10.0 & 6.0 & 4.8 & 6.3
\end{tabular}




\begin{tabular}{|c|c|c|c|c|c|c|c|c|c|c|c|c|}
\hline & Summer & 13.0 & 18.0 & 11.0 & 27.0 & 16.0 & 27.0 & 1.4 & 6.6 & 7.6 & 17.0 & 38.0 \\
\hline & Total & 1667.3 & 931.3 & 3040.4 & 11732.5 & 1000.0 & 2507.0 & 3231.2 & 6283.6 & 694.4 & 2529.4 & 4454.7 \\
\hline & Mean & 10.76 & 11.09 & 9.19 & 22.39 & 9.62 & 21.07 & 7.01 & 6.76 & 5.99 & 14.54 & 29.12 \\
\hline \multirow[t]{6}{*}{ Region 3} & Fall & 19.0 & 94.0 & 2.1 & 28.0 & 18.0 & 15.0 & 13.0 & 3.9 & 3.4 & 5.0 & 22.0 \\
\hline & Winter & 22.0 & 28.0 & 13.0 & 11.0 & 9.8 & 7.0 & 7.5 & 7.6 & 3.3 & 9.5 & 5.5 \\
\hline & Spring & 15.0 & 3.5 & 14.0 & 23.0 & 7.9 & 36.0 & 7.0 & 8.3 & 15.0 & 13.0 & 30.0 \\
\hline & Summer & 45.0 & 59.0 & 141.0 & 62.0 & 64.0 & 30.0 & 19.0 & 11.0 & 17.0 & 21.0 & 46.0 \\
\hline & Total & 10091.7 & 12037.2 & 16782.8 & 49396.6 & 15571.3 & 10577.8 & 6003.2 & 6977.3 & 3290.6 & 3867.1 & 9956.0 \\
\hline & Mean & 37.38 & 46.30 & 89.75 & 48.62 & 38.83 & 25.93 & 9.51 & 7.99 & 8.97 & 15.72 & 34.81 \\
\hline Accuracy & & 0.99 & 0.99 & 0.987 & 0.989 & 0.99 & 0.99 & 0.99 & 0.989 & 0.99 & 0.99 & 0.99 \\
\hline
\end{tabular}



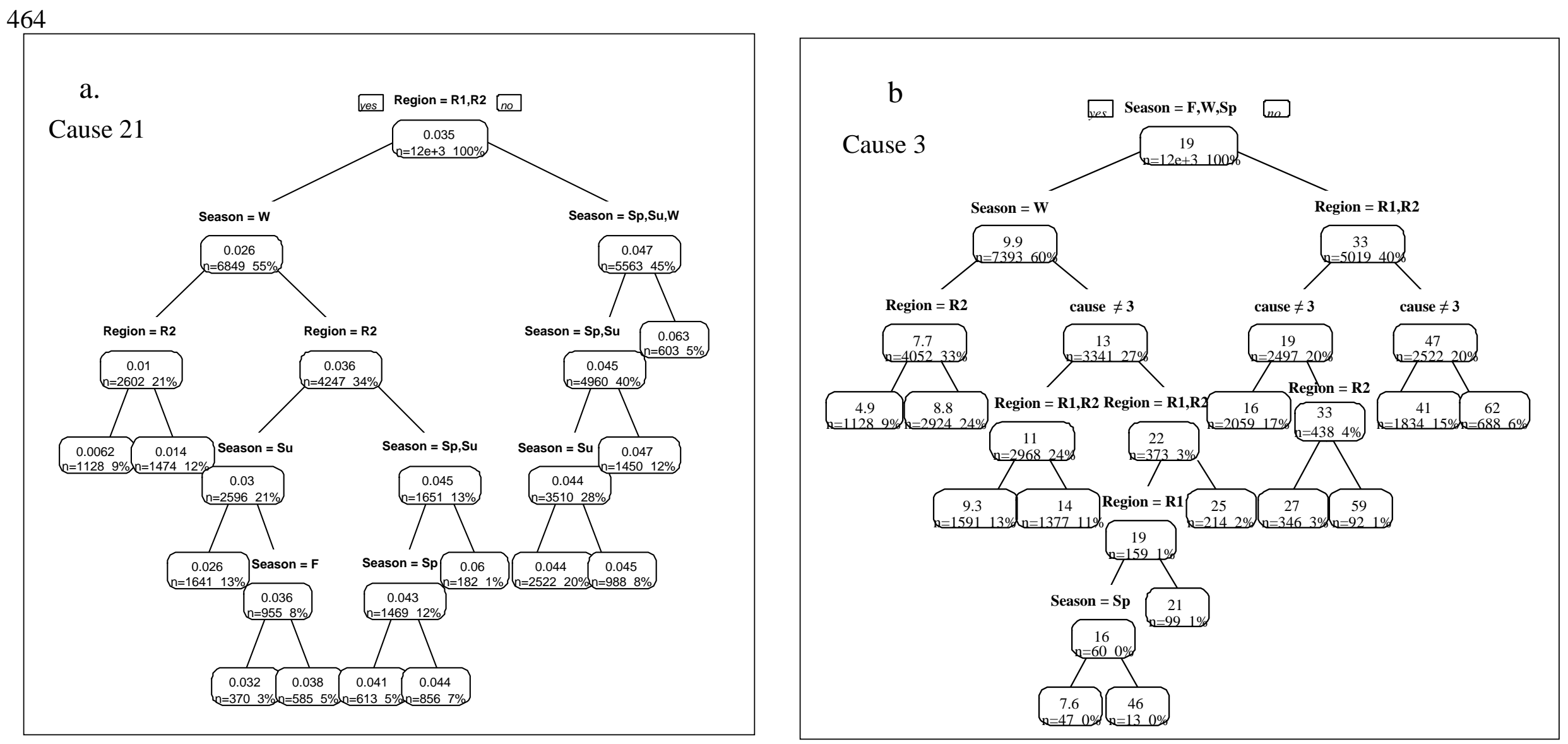

Figure 7: Two examples of regression trees giving the probability of occurrence of fires due to power lines (cause 21) (a) and the predicted mean burned area (in ha) due to undetermined arson (cause 3) (b) according to region and season: region best predicted the probability of occurrence of fires due to cause 21 and season best predicted the mean area burned by fires due to cause 3 . Analyses were run on the dataset of fires $\geq 1$ ha. 
tended to be spatially aggregated depending on their causality, especially the deliberate ones. Thus, mapping these hotspots would help to efficiently allocate means in terms of fire prevention or suppression.

The spatial variation of fire metrics has already been noted in previous works at a regional scale (Badia-Perpinyá and Pallares-Barbera 2006; Conedera et al. 2006) or at a more global scale (Syphard et al. 2009). Likewise, our results, obtained on the entire dataset, showed a spatial variation of both fire occurrence and total burned area which increased from regions 1 and 2 to region 3; region being the most significant factor of fire occurrence (contrary to the results of regression tree analyses run on the dataset of moderate and large fires). Our results also highlighted a seasonal variation of fire metrics which were higher in summer (and in spring to a lesser extent). Season mostly impacted total burned area (as well as the mean burned area in the regression tree analyses), likely because the climate conditions were driest and hottest in summer, especially in region 3. Accordingly, previous works already showed that fire weather, for instance the timing and the amount of precipitation each year especially in months before the fire season (usually attributed to the accumulation and drying patterns of herbaceous fine fuels), strongly influenced burned area (Davis and Michaelsen, 1995; Westerling et al. , 2003; Bradstock et al. 2009; Cary et al. 2009; Penman et al. 2011; Price and Bradstock 2011; Bradstock et al. 2012). However, the interaction between region and season highlighted in the analyses indicated that this trend could change (higher metrics in winter than spring in region 1). Eventually, this spatio-seasonal variation of fire metrics was found to be directly related to the fire causes. Indeed, some causes presented a strong spatio-seasonal pattern that can be due to climate conditions (i.e. stronger impact of fires due to power lines in fall in region 3) or to the seasonality of the practices, such as for forestry works. In this case, fuel treatments by prescribed burning, for instance, mainly occur between fall and spring, when the climate conditions are less severe. In Algeria, Meddour- 
Sahar et al. (2013) also highlighted a spatial variation of fires due to their cause, the highest

491 occurrence varying between deliberate-conflict, pyromania, and garbage dumps depending on 492 the region.

Undetermined arson presented a seasonal pattern (less pronounced in region 3) with

494 more frequent and severe fires in summer throughout the study area, agreeing with previous 495 works carried out in other Mediterranean countries (Moreno et al. 2011; Vilar del Hoyo et al. 496 2009). In the current work, intentional ignitions with identified motives (conflict, interest, 497 pyromania) mostly occurred in region 3 which was characterized, among others, by a high 498 population density which can be a driving factor of the occurrence of such fires. In this 499 region, better knowledge of these motives could be due to a better investigation of fire causes 500 or to their regional specificity. For instance, deliberate fires due to interest in pastoral 501 activities (deliberate-interest) which is a regular practice in the "département" Haute-Corse 502 (located in the Corsica island in region 3) had more severe effects in summer, when shepherds 503 seek to get free new grasslands by burning shrublands before the autumn rains. Meddour504 Sahar et al. (2013) underlined a similar problem in Algeria where deliberate fires due to 505 pastoral activities were one of the main fire causes in the country (in terms of occurrence) and 506 could be defined as a cultural trait of the local population. In region 3, pyromania was the 507 most frequent motive of deliberate fires, especially in summer and presented larger burned 508 areas in spring; however, this cause had a much lesser impact than undetermined arson. It is 509 worth noting that, according to the French classification of fire causes, pyromania takes into 510 account a large range of motives (from mental illness to drawing attention, vandalism, crime 511 concealment, etc.) which do not fall into the classes "deliberate-interest" and "deliberate512 conflict". In several other countries, pyromania has often been misappropriated and used as a 513 synonym of undetermined arson, resulting in an "artificial" increase in the occurrence of this 514 cause (Ganteaume et al. 2012). 
Agricultural work was another main cause of occurrence and total burned area (except

516 in summer), especially in regions 1 and 2. This cause encompassed ignitions due to 517 agricultural machines, legal pastoral fires, as well as burning residues and standing vegetation 518 before sowing (the latter being the most frequent). Lovreglio et al. (2010) and Martìnez et al. 519 (2009) showed that countries, such as Italy, Algeria and Spain, linked by a similar context of a 520 very traditional rural society, were highly impacted by agricultural fires (in terms of 521 occurrence). Furthermore, in Sardinia (Italy), agricultural and forestry activities caused most 522 fire ignitions (Lovreglio et al. 2014). However, these latter studies did not specify the season of maximum occurrence.

Regarding the spatial variation of fire causes, Syphard and Keeley (2015) found that the impact of fires due to equipment spatially varied in California, this cause entailing high fire effects in this region (however, only in terms of burned area), but in their work, the type of equipment responsible for these fires was not pinpointed. In the French classification of causes, these fires are part of the fires due to negligence during professional (causes 41 to 44 ) and private works (cause 51) but, within these categories, the proportion of fires due to equipment (i.e. machines or engines used during works) was low according to the Prométhée database. Frequently occurring along the roads, accidental fires set in garbage dumps and unintentional fires due to glowing items which were mostly cigarettes carelessly tossed by people, were more frequent in region 2 (mainly characterized by a high density of secondary roads), especially in spring and summer (only for garbage dumps). These fires were 535 responsible for more than $10 \%$ of the total area burned, in summer mostly, in regions 2 and 3 , 536 despite the mandatory brush-clearing along networks that should prevent the occurrence and 537 minimize the spread of such fires. Under normal weather conditions, cigarette butts do not 538 usually start large fires unless drought and fuel conditions exist (Markalas 1985; Satoh et al. 539 2003; Dainer 2003), thus making of roads and trails critical ignition points in severe climate 
conditions (Cardille et al. 2001; Romero-Calcerrada et al. 2008). Awareness-raising

541 campaigns regarding this cause must be reinforced in targeting especially tourists in summer.

542 Likewise, the same recommendations could be made for garbage dumps which was one of the

543 main causes in summer in regions 2 (regarding the occurrence) and 3 (regarding the burned 544 area). These two latter causes were also identified as problematic in Algeria and garbage 545 dumps, especially illegal ones, were among the most frequent causes of fires, as a direct 546 consequence of extreme population density, which made garbage collecting difficult 547 (Meddour-Sahar et al. 2013).

Even if the hotspots of natural fires (in terms of fire density) were spread throughout the study area (mostly in its SE part which also concentrated most fires regardless of the cause), at the regional level, region 1 was the most affected both in terms of occurrence and burned area (>10\% in summer mostly), as wet climate conditions can favor fires due to lightning strikes, especially at high elevation (Renkin and Despain 1992; Nash and Johnson 1996). It is worth noting that, on the whole, these fires remained small in size (mean burned area $<8$ ha), but were larger on average in winter, in region 3 (10 ha).

As noted in previous works (Ganteaume and Jappiot 2013; Meddour-Sahar et al. 2013; 556 Syphard and Keeley 2015), the high proportion of unknown causes (66\% on average in SE 557 France) can be a hindrance to a better understanding of the spatial variation of fire causes, as 558 well as to the development of any efficient fire policy aiming to reduce the occurrence of the 559 most deleterious fires. During the last few decades, investigations on fire causes have been 560 improved by the creation of official investigation teams, including forest rangers, police 561 officers, and fire fighters. These teams follow a procedure similar to that of a criminal 562 investigation to determine as precisely as possible the ignition point as well as the nature of its 563 cause. Unfortunately, this procedure is still not yet widely used in SE France. Our results 564 showed that knowledge of fire causes spatially varied, being better in region 1, perhaps 
because of the lower fire occurrence in this region. However, this poor knowledge can be explained in two main ways: (i) the investigations were either inconclusive or did not occur at all (Martín 2004 ; Castedo Dorado et al. 2007; Penman et al. 2013), and/or (ii) the database was not correctly filled out or was incomplete, as already found by Langhart et al. (1998) in Switzerland. Unknown causes contributed to a high extent of area burned (70 \% on average in the study area), especially in region 3 ( $73 \%$ of the burned area). However, in this latter region, a significant proportion of the fires with unknown cause was strongly suspected of being deliberate (Ganteaume et al. 2012).

\subsection{Focus on deleterious causes}

Agricultural works were one of the two main causes responsible for the highest fire effects in the study area. Fires due to this cause presented larger total area burned from fall to spring, when most agricultural burnings occurred (especially in winter) despite their small size (less than 9 ha on average regardless of region and season). Knowledge of these fires being better (very small proportion of undetermined professional works, e.g. cause 4) than that of the deliberate fires, for instance, they can be better targeted during fire prevention initiatives. pattern. Regardless of the region, this cause presented the highest fire effects, mostly in summer (>30\% of the total burned area) but also had a strong impact in fall in regions 1 and 3, as well as in spring in regions 2 and 3, mostly because the large size of such fires at these seasons. Region 3 was the most impacted by these deliberate fires likely because of long dry

586 summer conditions (conducive to high fire propagation) that characterized this region and 587 because, most of the year, this cause was the major source of ignitions. This important result 588 highlighted the need to extend preventive measures against such fires, before and after the fire season (summer in the study area). Usually, severe climate conditions (hot, dry and windy), 
entailing an extreme fire hazard, were preferentially targeted by arsonists in order to affect as

591 large burned areas as possible (Ganteaume and Jappiot 2013; Syphard and Keeley 2015); this

592 idea was, however, refuted by Mees (1991). The high proportion of these arson fires with

593 unidentified motives prevents understanding the behavioural patterns driving arson ignitions

594 because of its complexity, and mainly highlights a lack in the investigation of fire causes

595 (Mees 1991; Prestemon and Butry 2008; Syphard et al. 2008; Penman et al. 2013).

596 Moreover, as already highlighted by Syphard and Keeley (2015), some causes could 597 have disproportionally high fire effects, even if they were not the most frequent ones, and the 598 prevention of these causes must be targeted as a priority in each region. Our results also 599 showed that the same cause did not always impact both fire metrics in the same way. Some of 600 the least frequent causes can entail high fire effects (large total burned area), as it was 601 typically the case for fires due to glowing items (such as cigarette butts) in region 2 or to 602 garbage dumps and recreational activities in summer in region 3. Thereby, these causes also have to be carefully targeted by fire prevention measures. Accordingly, regardless of region 604 and season, for some causes, those driving high fire effects were not necessarily those 605 entailing fires with high mean burned area, such as forestry and agricultural works (small fires 606 but burning large areas, because of their high occurrence). Special attention should be also 607 paid to causes such as garbage dumps and power lines (especially in summer) that drove 608 globally small fire effects, but whose fires could be large, and thus could have high fire effect 609 on a smaller scale. As found in California (USA) and Australia (Cruz et al. 2012; Keeley et 610 al. 2012; Syphard and Keeley 2015), accidental fire causes due to power lines had a greater 611 impact in terms of burned area in region 3, especially in fall, when bad climate conditions 612 (autumn storms) can provoke ruptures of power lines. In this case, the fire effects due to these 613 installations could be mitigated using underground power lines in high risk wind corridors, as 614 proposed by Keeley et al. (2009) in California. 


\section{Conclusions and management implications}

618 The current work showed that spatial and seasonal patterns of fire metrics (region 3 being the 619 most affected part of the study area, especially in summer) often were the result of the nature 620 of fire causes (mainly undetermined arson in summer in region 3 and agricultural works, 621 especially in winter in regions 1 and 2).

In the study area, unknown causes contributed to a high extent of burned area, especially in region 3. This result highlighted the fact that, for better fire prevention, it is necessary to improve our knowledge of fire causes, mostly by increasing the investigations (in number and quality) and in accurately documenting the fire databases. As pointed out by Chas-Amil (2007), it is drastically important to better target the fire causes, especially the deliberate ones (and their different motives), in the implementation of fire prevention measures as proposed by Gonzalez-Olabarria et al. (2012). To improve intentional fire prevention, actions including educational campaigns and law enforcement measures that target sensitive areas could be developed, especially during the peak season of each region. In

631 summer in region 3, the impact of fires set by shepherds highlighted the need for supporting 632 these pastoral activities in a better management of the pastures (in increasing the 633 implementation of prescribed burnings, for instance). Some authors as Mees (1991) refuted 634 the idea that most arson fires occur under severe weather conditions. The author also validated 635 the need to maintain arson prevention programs (enhanced patrols and detection) during such 636 weather conditions. Our results also showed that prevention measures must be extended 637 before and after the fire season.

638 Regarding the fires due to negligence, ignitions set by professional and private works depended, on the one hand, on the characteristics of the location of these works (regions) and, 
640 on the other hand, on the seasonal practices related to these activities (such as brush-clearing

641 and prescribed burning in forestry works, or burning to clean gardens in private works). The

642 prevention of these fires should require a better awareness of people (professionals or not) in

643 order to modify their behaviour for safer practices (improvements in the management of

644 these activities and in the training of professionals for prescribed burning activities, for

645 instance).

646 In the future, according to global change, the climate conditions will likely become 647 warmer and dryer in the northern part of the study area, i.e. region 1, becoming more like 648 those of regions 2 and 3. This change, combined with the land cover/land use change, will 649 increase the fire risk in this region, which is currently the lowest in SE France. In a further 650 work, the study of the temporal variation of fires as well as of the driving factors of their 651 causes will attempt to better understand the role of global change on the fire metrics and 652 causes. This improvement in knowledge of fire causes will allow a better prediction of these 653 changes on the local scale, in adapting fire prevention in the most sensitive areas where the 654 population is currently less aware of the fire risk.

655

656

657 Acknowledgement

658 The authors sincerely thank Aimee Mac Cormack for English revision.

659

660 
662 1.Badia-Perpinyá, A. and Pallares-Barbera, M. (2006) Spatial distribution of ignitions in 663 Mediterranean peri-urban and rural areas: the case of Catalonia. Int. J. Wildland Fire, 15, 187664196.

665 2.Bar-Massada, A., Hawbaker, T.J., Stewart,S.I. and Radeloff, V.C. (2012) Combining 666 Satellite-Based Fire Observations and Ground-Based Lightning Detections to Identify 667 Lightning Fires Across the Conterminous USA. IEEE Journal of selected topics in applied 668 earth observations and remote sensing, 5 (5), 1438-1447.

669 3.Bradstock, R.A., Cohn, J.S., Gill, A.M., Bedward, M. and Lucas, C. (2009) Prediction of 670 the probability of large fires in the Sydney region of south-eastern Australia using fire

4.Bradstock, R.A., Cary, G.J., Davies, I., Lindenmayer, D.B., Price, O.F. and Williams, R.J. (2012) Wildfires, fuel treatment and risk mitigation in Australian eucalypt forests: Insights from landscape-scale simulation. J. Env. Manag., 105, 66-75. doi:10.1016/J.JENVMAN. 2012.03.050

5.Camia, A., Durrant T. and San-Miguel-Ayanz J., 2013. Harmonized classification scheme of fire causes in the EU adapted for the European Fire Database of EFFIS. JRC scientific and policy reports, Luxembourg, publication office of the EU.

6.Cardille, J.A., Ventura, S.J. and Turner, M.G. (2001) Environmental and social factors 
incendios en las estrategias de prevención y extinción. Un caso de estudio. In 'Proceedings of the 4th International Wildland Fire Conference' (13-17 May 2007), Seville, Spain.

9.Catry, F.X., Rego, F. and Bacao, F. (2009) Modeling and mapping wildfire ignition risk in Portugal. Int. J. Wildland Fire, 18, 1-11.

10.Chas Amil, M.L. (2007) Forest fires in Galicia (Spain): threats and challenges for the future. J. For. Ecol., 13, 1-5.

694

11.Conedera, M., Cesti, G., Pezzatti, G.B., Zumbrunnen, T. and Spinedi, F. (2006) Lightning695 induced fires in the Alpine region: An increasing problem. In Viegas, D.X. (ed) 'Proceedings of the $V^{\text {th }}$ International Conference on Forest Fire Research' (27-30 November 2006), Figueira da Foz, Portugal. [CD-ROM]. Portugal, ADAI/CEIF University of Coimbra. $9 \mathrm{~S}$.

699

12.Cruz, M.G., Sullivan, A.L., Gould, J.S., Sims, N.C., Bannister, A.J., Hollis, J.J. and 700 Hurley, R.J. (2012) Anatomy of a catastrophic wildfire: the Black Saturday Kilmore East fire in Victoria, Australia. For. Ecol. Manag., 284, 269-285.

13.Dainer, J. (2003) 'Can cigarette butts start bushfires?' Thesis, University of Technology, Sydney.

14.Davis, F.W. and Michaelsen J. (1995) Sensitivity of fire regime in chaparral ecosystems to 705

15.De Martonne, E. (1926) Aréisme et indice d'aridité. Comptes rendus Académiques des Mediterranean-Type Ecosystem' (pp. 435-456), Springer, NewYork. Sciences, 181, 1395-1398.

16.Díaz-Delgado, R., Lloret, F. and Pons, X. (2004) Spatial patterns of fire occurrence in Catalonia, NE, Spain. Landsc. Ecol., 19, 731-745. 
712 18.EC (2014) Forest fires in Europe, Middle East and North Africa 2013. Luxembourg, 713 publication office of the EU.

714 19.Ganteaume, A., Camia A., Jappiot M., San Miguel-Ayanz J., Long-Fournel, M. and 715 Lampin C. (2012) A Review of the Main Driving Factors of Forest Fire Ignition Over $716 \quad$ Europe. Environ. Manag., 51 (3), 651-662.

717 20.Ganteaume, A. and Jappiot, M. (2013) What causes large fires in Southern France. For. 718 Ecol. Manag., 294, 76-85.

21.Ganteaume, A. and Long-Fournel, M. (2015) Driving factors of fire density can spatially vary at the local scale in SE France. Int. J. Wildland Fire, 24(5), 650-664.

22.Gaussen, H. and Bagnouls, F. (1952) L’indice xérothermique. Bulletin des géographes français 222-223, 10-16.

23.Genton, M.G., Butry, D.T., Gumpertz, M.L. and Prestemon, J. (2006) Spatio-temporal 724 analysis of wildland fire ignitions in the St Johns River Water Management District, Florida. Int J Wildland Fire, 15, 87-97.

24.Gonzalez-Olabarria, J.R., Brotons, L., Gritten, D., Tudela, A. and Teres, J.A. (2012) Identifying location and causality of fire ignition hotspots in a Mediterranean region. Int.

25.Keeley, J. and Fotheringham, C. (2001) Historic fire regime in southern California shrublands. Conserv. Biol., 15, 1536-1548. doi:10.1046/J.1523-1739.2001.00097.X. Southern California wildfires: lessons in complexity. Journal of Forestry, 107, 287-296.

27.Keeley, J.E., Bond, W.J., Bradstock, R.A., Pausas, J.G. and Rundel, P.W. (2012) Fire in Mediterranean Ecosystems Ecology, Evolution and Management. Cambridge University Press: Cambridge, UK. 
28.Koutsias, N., Arianoutsou, M., Kallimanis, A.S., Mallinis, G., Halley, J.M. and Dimopoulos, P. (2012) Where did the fires burn in Peloponnisos, Greece the summer of 2007? Evidence for a synergy of fuel and weather. Agricultural and Forest Meteorology, $156,41-53$

29.Lampin-Maillet, C., Jappiot, M., Long, M., Bouillon, C., Morge, D. and Ferrier, J.P. (2010) Mapping wildland-urban interfaces at large scales integrating housing density and vegetation aggregation for fire prevention in the South of France. J. Environ. Manage, $91,732-741$.

30.Langhart, R., Bachmann, A. and Allgöwer, B. (1998) Spatial and Temporal Patterns of Fire Occurrence (Canton of Grison, Switzerland). In: Viegas, D.X. (ed) 'Proceedings of the 3rd International Conference on Forest Fire Research $/ 14^{\text {th }}$ Conference on Fire and Forest Meteorology', Vol.2 (pp 2279-2292), Luso, Portugal (16-20 November 1998).

31.Lovreglio, R., Rodrigues, M., Notarnicola, A. and Leone, V. (2010) From fire motives survey to prevention: the case of Cilento and Vallo di Diano National Park (Italy). In Viegas, D.X. (ed) 'Advances in Forest Fire Research' (pp. 301), Coimbra Portugal.

32.Lovreglio, R., Mou, G., and Leone, V. (2014) Forest fire motives in Sardinia through the perception of experts. In Viegas, D.X. (ed) 'Advances in Forest Fire Research' (pp. 1855-1862), Coimbra Portugal.

33.Markalas, S. (1985) Laboratory experiments on the role of cigarette ends in lighting fires. Allgemeine Forstund Jagdzeitung, 156, 193-197. [In German]

34.Martín, P. (2004). Towards methods for investigating on wildland fire causes. EUFIRELAB, EVR1-CT-2002-40028, Deliverable D-05-02.

35.Martínez, J., Vega-Garcia, C. and Chuvieco, E. (2009) Human-caused wildfire risk rating for prevention planning in Spain. J. Environ. Manage., 90, 1241-1252. doi:10.1016/J.JENVMAN.2008.07.005 
36.Meddour-Sahar, O., Meddour, R., Leone, V., Lovreglio, R. and Derridj, A. (2013) Analysis of forest fires causes and their motivations in northern Algeria: the Delphi method. iForest Biogeosciences and Forestry, 6(4), 247-254. doi:10.3832/IFOR0098006.

37.Mees, R. (1991. Is Arson Associated with Severe Fire Weather in Southern California? Int. J. Wildland Fire, l(2), 97-100.

38.Moreno, M.V., Malamud, B.D. and Chuvieco, E.A. (2011) Wildfire frequency-area Statistics in Spain. Procedia Environmental Sciences, 7, 182e187.

39.Nash, C.H. and Johnson, E.A. (1996) Synoptic climatology of lightning-caused forest fires in subalpine and boreal forests. Canadian J. For. Res, 26, 1859-1874. doi:10.1139/X26211.

40.Penman, T.D., Price, O. and Bradstock, R.A. (2011) Bayes nets as a method for analysing the influence of management actions in fire planning. Int. J. Wildland Fire, 20, 909-920. doi:10.1071/WF10076.

41.Penman, T.D., Bradstock, R.A. and Price, O. (2013) Modelling the determinants of ignition in the Sydney Basin, Australia: implications for future management. Int. J. Wildland Fire, 22, 469-478. doi:10.1071/WF12027.

42.Penman, T.D., Collins L., Syphard, A.D., Keeley, J.E. and Bradstock, R.A. (2014) Influence of Fuels, Weather and the Built Environment on the Exposure of Property to Wildfire. PLOSONE, 9, e111414.

43.Prestemon, J.P. and Butry, D.T. (2008) Wildland arson management. In Holmes, T.P., Prestemon, J.P., Abt, K.L. (Eds) 'The Economics of Forest Disturbances' (pp. 123-147). (Springer: Dordrecht, the Netherlands). 
784 44.Prestemon, J.P., Pye, J.M., Butry, D.T., Holmes, T.P. and Mercer, D.E. (2002)

785 Understanding broadscale wildfire risks in a human-dominated landscape. For. Sci., 48, $786 \quad 685-693$.

787 45.Price, O.F. and Bradstock, R.A. (2011) The influence of weather and fuel management on 788 the annual extent of unplanned fires in the Sydney region of Australia. Int. J. Wildland $789 \quad$ Fire, 20, 142-151.

790 46.R Development Core Team (2005) R: A Language and Environment for Statistical 791 Computing, Reference Index Version v. 2.5.1. R Foundation for Statistical Computing, 792 Vienna, Austria.

793 47.Renkin, R.A. and Despain, D.G. (1992) Fuel moisture, forest type, and lightning caused 794 fire in Yellowstone National Park. Canadian J. For. Res. 22, 37-45. doi:10.1139/X92795 005.

48.Riley, S.J., DeGloria, S.D. and Elliot R. (1999) A terrain ruggedness index that quantifies topographic heterogeneity. Intermountain J. Sci., 5, 1-4.

49.Romero-Calcerrada, R., Novillo, C.J., Millington, J.D.A. and Gomez-Jimenez, I. (2008) GIS analysis of spatial patterns of human-caused wildfire ignition risk in the SW of Madrid (central Spain). Landsc. Ecol, 23, 341-354.

50.Satoh, K., Zhong, Y.L. and Yang, K.T. (2003) Study of forest fire initiation due to lit 802

51.Stephens, S.L. (2005) Forest fire causes and extent on United States Forest Service lands. Int. J. Wildland Fire, 14, 213-222. Hall, London-New York. 
809

810

811

812

813

814

815

816

817

818

819

820

821

822

823

824

825

826

53.Syphard, A.D., Radeloff, V.C., Keuler, N.S., Taylor, R.S., Hawbaker, T.J., Stewart, S.I. and Clayton; M.K. (2008) Predicting spatial patterns of fire on a southern California landscape. Int. J. Wildland Fire, 17, 602-613.

54.Syphard, A.D., Radeloff, V.C., Hawbaker, T.J.,and Stewart, S.I. (2009) Conservation Threats Due to Human-Caused Increases in Fire Frequency in Mediterranean-Climate Ecosystems. Conserv Biol, 23, 758-769.

55.Syphard, A.D. and Keeley, J.E. (2015) Location, timing and extent of wildfire vary by cause of ignition. Int. J. Wildland Fire, 24(1), 27-36. doi.org/10.1071/WF14024.

56.Vilar Del Hoyo, L., Martin, P. and Camia, A. (2009) Analysis of human-caused wildfire occurrence and land use changes in France, Spain and Portugal. In Chuvieco, E., and Lasaponara, R. (Eds.) 'Proceedings of the VII International EARSeL Workshop: Advances on Remote Sensing and GIS applications in Forest Fire Management' (pp. 8589). Potenza (Italy).

57.Westerling, A.L., Gershunov, A., Brown, T.J., Cayan, D.R. and Dettinger, M.D. (2003) Climate and wildfire in the western United States. Bulletin of the American Meteorological Society, 84, 595-604. 
